Article

\title{
An Efficient Solvent-Free Synthesis of 2-Hydroxy-2- (trifluoromethyl)-2H-chromenes Using Silica-Immobilized L-Proline
}

\author{
Cuilian Xu *, Guoyu Yang, Caixia Wang, Sufang Fan, Lixia Xie and Ya Gao \\ School of Science, Henan Agricultural University, Zhengzhou 450002, China; \\ E-Mails: ygy1096@sina.com.cn (G.Y.); wcx670815@163.com (C.W.); \\ fansufang123@163.com (S.F.); toxielix@163.com (L.X.); 15136423631@163.com (Y.G.) \\ * Author to whom correspondence should be addressed; E-Mail: xucuilian666@126.com; \\ Tel.: +86-371-6355-8138; Fax: +86-371-6355-8139.
}

Received: 15 July 2013; in revised form: 7 September 2013 / Accepted: 11 September 2013 / Published: 26 September 2013

\begin{abstract}
An efficient synthesis of 2-hydroxy-2-(trifluoromethyl)-2H-chromene-3-carboxylates was carried out under solvent-free conditions in an oven or microwave oven via the Knoevenagel condensation of salicylaldehydes with ethyl trifluoroacetoacetate followed by intramolecular cyclization in the presence of silica-immobilized L-proline. The structures of the title compounds were characterized by IR, ${ }^{1} \mathrm{H}-\mathrm{NMR},{ }^{13} \mathrm{C}-\mathrm{NMR}, \mathrm{HRMS}$ and X-ray single crystal diffraction. The improved method described herein is economical, easily-operated and environmentally friendly. Furthermore, the catalyst can be recovered conveniently and reused without obvious loss of activity.
\end{abstract}

Keywords: solvent-free; 2-hydroxy-2-(trifluoromethyl)-2H-chromene-3-carboxylates; synthesis; Knoevenagel condensation; silica-immobilized L-proline

\section{Introduction}

The chromene ring moiety has been identified as one of the privileged scaffolds for drug discovery due to its broad spectrum of biological activity [1-3]. Among various chromene isomers, $2 H$-chromenes are attracting much more interest from chemists because compounds that possess this group show a variety 
of activities, including antiviral [4,5], anti-tumor [6,7], anti-bacterial/antimicrobial [8,9], fungicidal [10], antioxidative [11], insecticidal agents [12], and activator of potassium channels effects [13,14].

On the other hand, although introduction of fluorine atoms into organic compounds has been known as one of the best strategies for the enhancement or modification of their original biological activities [15-19], up to now there are limited reports on the preparation of 2-fluoroalkylated $2 \mathrm{H}$-chromenes. Laurent et al. reported the synthesis of 2-(trifluoromethyl)- and 2-(perfluoroalkyl)-2-hydroxy-2 $H$-chromenes by intramolecular cyclization of 3-(perfluoroalkyl)-3-phenoxypropenals in the presence of aluminum chloride [20]. Wang et al. reported the synthesis of 2-trifluoromethyl-2H-benzopyran-3-carboxylic acids from the reaction of substituted salicylaldehydes with ethyl trifluorocrotonate and found these potential as novel potent and selective cyclooxygenase-2 inhibitors [21-23]. Recently Chizhov et al. prepared ethyl 6-substituted 2-hydroxy-2-(trifluoromethyl)-2H-chromene-3-carboxylates via the Knoevenagel condensation of salicylaldehydes with ethyl trifluoroacetoacetate in the presence of piperidinium acetate [24]. Li synthesized novel coumarin dyes bearing trifluoromethyl substituents by the condensation of 3-(trifluoroacetyl)coumarins with various arylhydrazines and studied their fluorescence activities [25]. Zhu's group reported a Lewis acid-promoted reaction of 2-(trifluoromethyl)-2-hydroxy- $2 H$-chromenes with indoles and thiophenols, and obtained both 2-functionalized-2-trifluoromethyl-3-ethoxycarbonyl-2 $\mathrm{H}$-chromenes and 4-functionalized-2-trifluoromethyl-3-ethoxycarbonyl-4H-chromenes [26,27]. To the best of our knowledge, however, there are no reports on the synthesis of 2-hydroxy-2-(trifluoromethyl)-2H-chromenes under solvent-free conditions.

Recently the progress in the field of solvent-free reactions has provided organic chemists with an efficient synthetic method of great promise [28-30]. Particularly this technique has been coupled with microwave-assisted organic synthesis (MAO), resulting in clean, easy-to-perform, cheap, safe and environmentally friendly conditions which are widely used as synthetic tools under "Green Chemistry" conditions [31,32]. Difficult recycling of homogeneous catalysts, such as piperidinium acetate, prompted us to find a suitable heterogeneous catalyst. L-Proline and its analogues have been extensively investigated as catalysts for many reactions; much effort has been dedicated to the immobilization and recycling of L-proline and its analogues with the assistance of organic and inorganic supports [33-35].

In continuation of our work on green synthetic strategies for the preparation of heterocyclic compounds [36,37], we were prompted to use a solvent-free methodology for the synthesis of 2-hydroxy-2-(trifluoromethyl)-2H-chromenes from salicylaldehydes and ethyl trifluoroacetoacetate under solvent-free conditions in the presence of silica-immobilized L-proline (L-proline/ $\mathrm{SiO}_{2}$ ).

\section{Results and Discussion}

\subsection{Synthesis}

Initially, the reaction $\mathrm{n}$ of salicylaldehyde (1a) and ethyl trifluoroacetoacetate (2) was tested without any catalyst under neat conditions, but almost no product was obtained without or with microwave irradiation (Scheme 1 and Table 1, entries 1-2). After adding $20 \mathrm{~mol} \%$ of L-proline/ $\mathrm{SiO}_{2}$, the reaction afforded the product 3a in $80 \%$ (entry 5) and 69\% (entry 3) yield, respectively, with or without MW irradiation (MWI), under solvent-free conditions. Thus, the reaction could be catalyzed by 
L-proline/ $\mathrm{SiO}_{2}$ and the reaction rate could be increased by MWI. Increasing the loading of catalyst improved the yield and shortened the reaction time (entries 4-7), however, the yield did not increase when the amount of the catalyst was more than $30 \mathrm{~mol} \%$ of substrate 1a (entry 7). Next, the reaction with different ratios of $\mathbf{1 a}$ to $\mathbf{2}$ was examined under $30 \mathrm{~mol} \% \mathrm{~L}$-proline $/ \mathrm{SiO}_{2}$ catalysis. It was observed that the variation of this ratio had a great influence on the yield. The yield of $\mathbf{3 a}$ reached a maximum at the molar ratio of $1: 1.5$ and $1: 2$. When the quantity of compound 2 continued to increase, yield was reduced and more side-products were observed according to HPLC (entries 10-11). Therefore, the ratio of $\mathbf{1 a}$ to $\mathbf{2}$ was optimized as 1:1.5. After the product was extracted thoroughly with dichloromethane, the separated catalyst was subjected to another cycle with fresh reactants under similar conditions. It was observed that the yield was nearly the same. The above procedure was repeated for three cycles, and no substantial loss in the catalytic activity of the immobilized catalyst was observed (entries 12-13).

Scheme 1. Solvent-free synthesis of compound 3a.

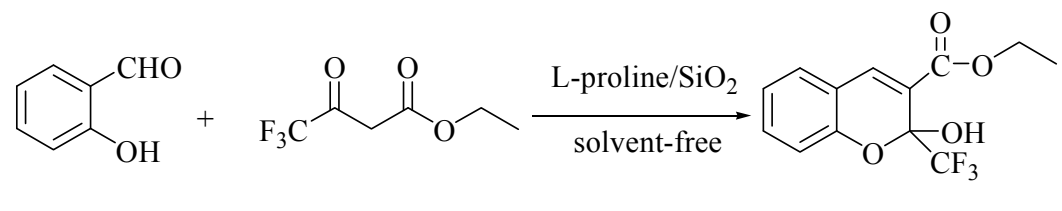

$1 \mathbf{a}$

2

3a

Table 1. Optimization for the synthesis of $2 H$-chromene $3 \mathbf{a}^{\mathrm{a}}$.

\begin{tabular}{ccccc}
\hline Entry & Mol ratio of 1a and 2 & Loading of catalyst $\left(\mathbf{m o l} \mathbf{\%}^{\mathbf{a}}{ }^{\mathbf{a}}\right.$ & Time & Yield $^{\mathbf{b}} \mathbf{( \% )}$ \\
\hline 1 & $1: 1.5$ & 0 & $6 \mathrm{~h}^{\mathrm{c}}$ & 0.5 \\
2 & $1: 1.5$ & 0 & $20 \mathrm{~min}$ & 0.7 \\
3 & $1: 1.5$ & 20 & $6 \mathrm{~h}^{\mathrm{c}}$ & 69 \\
4 & $1: 1.5$ & 10 & $15 \mathrm{~min}$ & 38 \\
5 & $1: 1.5$ & 20 & $18 \mathrm{~min}$ & 80 \\
6 & $1: 1.5$ & 30 & $14 \mathrm{~min}$ & 82 \\
7 & $1: 1.5$ & 40 & $9 \mathrm{~min}$ & 82 \\
8 & $1: 1$ & 30 & $17 \mathrm{~min}$ & 43 \\
9 & $1: 2$ & 30 & $14 \mathrm{~min}$ & 82 \\
10 & $1: 2.5$ & 30 & $15 \mathrm{~min}$ & 56 \\
11 & $1: 3$ & 30 & $15 \mathrm{~min}$ & 38 \\
12 & $1: 1.5$ & 30 & $14 \mathrm{~min}$ & $82^{\mathrm{d}}$ \\
13 & $1: 1.5$ & 30 & $14 \mathrm{~min}$ & $80^{\mathrm{e}}$ \\
\hline
\end{tabular}

${ }^{\mathrm{a}}$ Reaction conditions: 1a $(7 \mathrm{mmol}), \mathrm{L}-\mathrm{proline} / \mathrm{SiO}_{2}(4.5 \mathrm{~g})$, MWI $(126 \mathrm{~W}) .{ }^{\mathrm{b}}$ Isolated yield based on 1. All yields are the average of two runs based on fresh catalyst. ${ }^{\mathrm{c}}$ Heating in the oven at $80{ }^{\circ} \mathrm{C}$ under solvent-free condition. ${ }^{\mathrm{d}}$ Catalyst was reused in the second run. ${ }^{\mathrm{e}}$ Catalyst was reused in the third run.

To evaluate the efficiency of this methodology, various substituted salicylaldehydes $\mathbf{1 b}-\mathbf{1 l}$ were next reacted with ethyl trifluoroacetoacetate under optimal conditions (Scheme 2). The results are shown in Table 2. 
Scheme 2. Solvent-free synthesis of compound $\mathbf{3 a}-\mathbf{l}$.

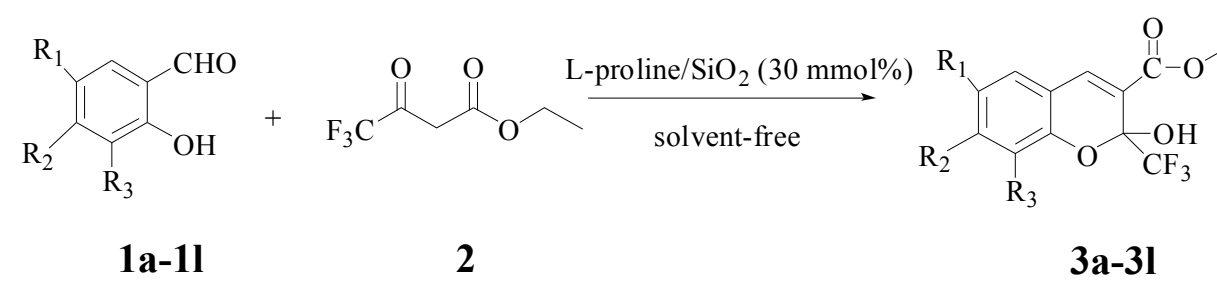

Table 2. Synthesis of 2-hydroxy-2-(trifluoromethyl)-2H-chromenes 3a-l under optimum conditions.

\begin{tabular}{ccccccccc}
\hline \multirow{2}{*}{ Entry } & \multirow{2}{*}{$\mathbf{R}_{\mathbf{1}}$} & \multirow{2}{*}{$\mathbf{R}_{\mathbf{2}}$} & \multirow{2}{*}{$\mathbf{R}_{\mathbf{3}}$} & \multirow{2}{*}{ Product } & \multicolumn{2}{c}{ MWI (126 W) } & \multicolumn{2}{c}{ Without MWI $^{\mathbf{b}}$} \\
\cline { 6 - 9 } & & & & Time (min) & Yield ${ }^{\mathrm{a}}(\%)$ & Time (h) & Yield $^{\mathrm{a}}(\mathbf{\%})$ \\
\hline 1 & $\mathrm{H}$ & $\mathrm{H}$ & $\mathrm{H}$ & $\mathbf{3 a}$ & 12 & 82 & 6 & 75 \\
2 & $\mathrm{Cl}$ & $\mathrm{H}$ & $\mathrm{H}$ & $\mathbf{3 b}$ & 17 & 89 & 6 & 81 \\
3 & $\mathrm{Br}$ & $\mathrm{H}$ & $\mathrm{H}$ & $\mathbf{3 c}$ & 16 & 85 & 6 & 77 \\
4 & $\mathrm{Cl}$ & $\mathrm{H}$ & $\mathrm{Cl}$ & $\mathbf{3 d}$ & 12 & 87 & 8 & 80 \\
5 & $\mathrm{Br}$ & $\mathrm{H}$ & $\mathrm{Br}$ & $\mathbf{3 e}$ & 16 & 88 & 6 & 81 \\
6 & $\mathrm{H}$ & $\mathrm{H}$ & $\mathrm{OMe}$ & $\mathbf{3 f}$ & 12 & 70 & 6 & 69 \\
7 & $\mathrm{H}$ & $\mathrm{OMe}$ & $\mathrm{H}$ & $\mathbf{3 g}$ & 8 & 68 & 8 & 65 \\
8 & $\mathrm{H}$ & $\mathrm{H}$ & $\mathrm{OEt}$ & $\mathbf{3 h}$ & 16 & 72 & 8 & 66 \\
9 & $\mathrm{Me}$ & $\mathrm{H}$ & $\mathrm{H}$ & $\mathbf{3 i}$ & 18 & 81 & 6 & 65 \\
10 & $\mathrm{H}$ & $\mathrm{OH}$ & $\mathrm{H}$ & $\mathbf{3 j}$ & 17 & 66 & 8 & 67 \\
11 & $\mathrm{NO}$ & $\mathrm{H}$ & $\mathrm{H}$ & $\mathbf{3 k}$ & 6 & 92 & 2 & 83 \\
12 & $\mathrm{H}$ & $-\mathrm{CH}=\mathrm{CH}-$ & $\mathbf{3 l}$ & 18 & 74 & 8 & 68 \\
\hline
\end{tabular}

${ }^{\mathrm{a}}$ Isolated yield based on $1 .{ }^{\mathrm{b}}$ Heating in the oven at $80^{\circ} \mathrm{C}$ under solvent-free conditions.

As can be seen from Table 2, electron-withdrawing (entries 2-5, entry 11) and electron-donating groups (entries 7-10, entry 12) at various positions of the benzene rings are well tolerated. The aromatic aldehydes with electron-donating groups afforded lower yields in comparision with those with electron-withdrawing groups. For instance, 4-methoxy-2-hydroxylbenzaldehyde (1g) and 4-hydroxy-2-hydroxylbenzaldehyde (1j) gave products $\mathbf{3 g}$ and $\mathbf{3 j}$ with yields of $68 \%$ and $66 \%$ under MWI, respectively (entries 7 and 10), but compounds $\mathbf{1 b}$ and $\mathbf{1 k}$ afforded the products $\mathbf{3 b}$ and $\mathbf{3 k}$ with yields of $89 \%$ and $92 \%$ (entries 2 and 11), respectively. On the other hand, the reactions required longer times and gave relatively lower yields by the alternative method employing heating in the oven at $80{ }^{\circ} \mathrm{C}$. In most cases the microwave-assisted conditions were found to be superior to those without MWI, and the chromenes 3a-3I were obtained in better yields (66\%-92\%), compared with yields of $65 \%-83 \%$ in the same reaction without MWI.

The proposed catalytic cycle is shown in Scheme 3. The L-proline-catalyzed reaction proceeds via an enamine intermediate $\mathbf{A}$. Intermediate $\mathbf{A}$ reacts with salicylaldehyde via transition state $\mathbf{B}$ to give intermediate $\mathbf{C}$, which produced the Knoevenagel product $\mathbf{E}$ through hydrolysis and dehydration. The subsequent cyclization occurs to yield 3a by addition of phenoxide ion to the more electrophilic carbonyl group rather than to the ester group forming intermediate $\mathbf{G}$. 
Scheme 3. Proposed mechanism.
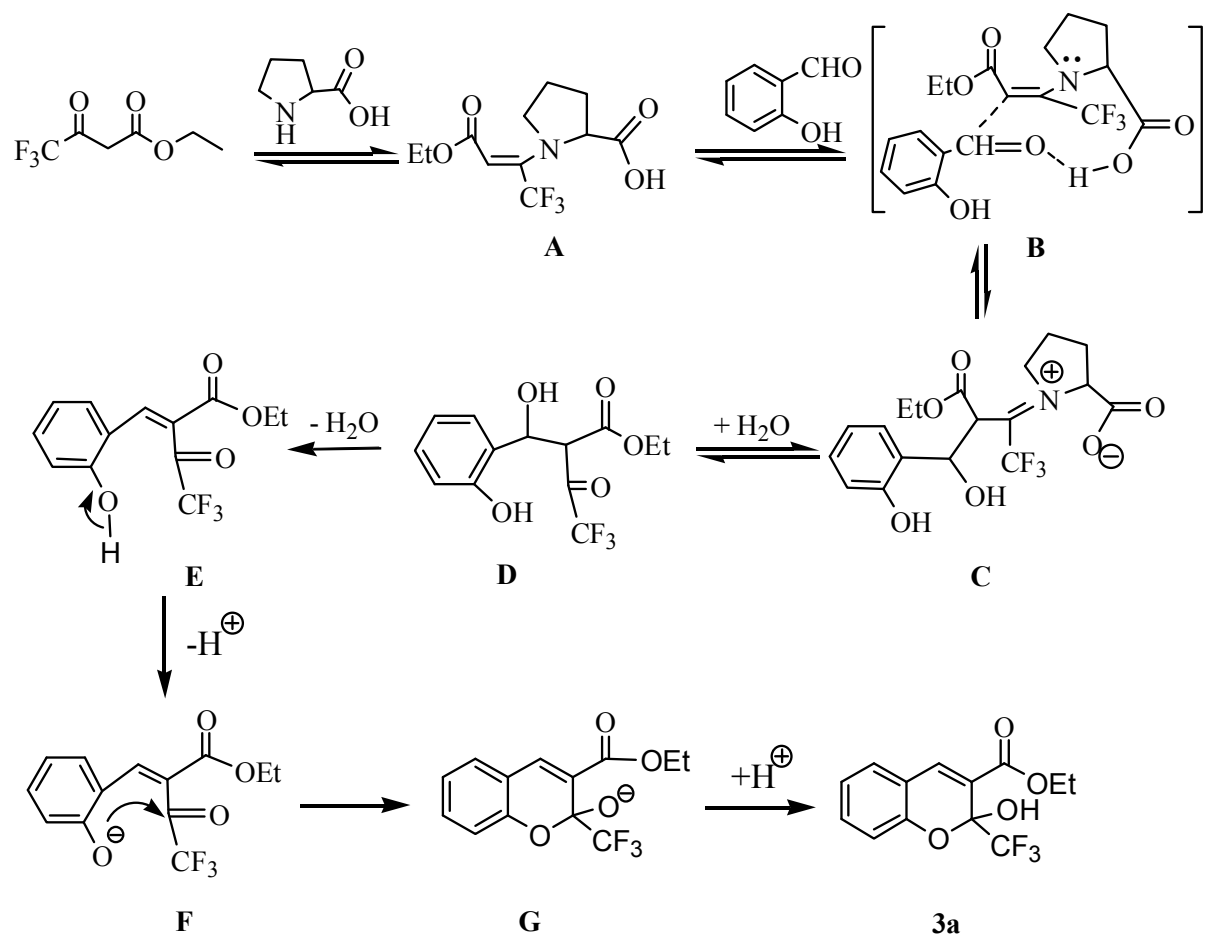

\subsection{Structural Characterization of Chromenes 3a-1}

The chemical structures of chromenes $\mathbf{3 a}-\mathbf{l}$ were characterized by IR, ${ }^{1} \mathrm{H}-\mathrm{NMR},{ }^{13} \mathrm{C}-\mathrm{NMR}$ and HRMS. All of the data in the spectra were in good accordance with the structures. The IR spectra of 3a-l displayed $\mathrm{OH}$ absorption in the range $3110-3443 \mathrm{~cm}^{-1}$, and the intensive absorption bands in the range $1671-1721 \mathrm{~cm}^{-1}$ attributed to the $\mathrm{C}=\mathrm{Os}$ in the ester groups. The diagnostic signal for the proton H-4 in chromenes 3a-l appeared at 7.64-8.47 ppm, which is usually in lower field than common aromatic protons are. The signal for $-\mathrm{OH}$ at $\mathrm{C}-2$ in 3a-l, which appeared at 7.22-9.60 ppm, was shifted downfield because of the formation of intromolecular $\mathrm{H}$-bonding between the $\mathrm{OH}$ and $\mathrm{O}$ atom in the carboxyl group and neighboring electron-withdrawing $\mathrm{CF}_{3}$ group. In the ${ }^{13} \mathrm{C}-\mathrm{NMR}$ spectra of $\mathbf{3 a}-\mathbf{l}$, the quartets of $\mathrm{CF}_{3}$ and $\mathrm{C}-2$ atom with their corresponding coupling constants ${ }^{1} J_{\mathrm{C}, \mathrm{F}}=289-291 \mathrm{~Hz}$ and ${ }^{2} J_{\mathrm{C}, \mathrm{F}}=33.6-36.4 \mathrm{~Hz}$, appeared at $122.0-123.0 \mathrm{ppm}$ and $95.2-96.6 \mathrm{ppm}$ respectively, similar to the related data $[24,38]$. Compounds $\mathbf{3 a}-\mathbf{l}$ all showed the molecular-ion peak $[\mathrm{M}+\mathrm{Na}]^{+}$in the high resolution mass spectrum, matching with the caculated data.

The structures of $2 \mathrm{H}$-chromenes were further confirmed by the X-ray diffraction determination of single crystals of compounds $\mathbf{3 a}$ and $\mathbf{3 c}$ (single crystal X-ray diffraction data of compounds $\mathbf{3 a}$ and 3c are deposited with CCDC Nos. 845964 and 845962, respectively). The perspective and packing views are shown in Figures $1 \mathrm{a}, \mathrm{b}$ and $2 \mathrm{a}, \mathrm{b}$ respectively. The crystal data and refinement details are given in Table 3. It is seen that compounds $\mathbf{3 a}$ and $\mathbf{3 c}$ are isomorphous, and they crystallize in the monoclinic space P21/c with four molecules in the unit cell. The value of O1-C8 bond length is 1.374 (5) $\AA$ in 3c, which is slightly shorter, compared with 1.396(4) $\AA$ in 3a. This is probably due to the inductive negative effect of the halogen atom on the lactone $\mathrm{O}$ atom (O1) lone pair of electrons. In 3a and 3c molecules, the carboxylate carbonyl groups (O3) are out of the plane defined by atoms $\mathrm{C} 2-\mathrm{C} 9$ by 3.6 and $6.6^{\circ}$, respectively. The 2-hydroxy groups $(\mathrm{O} 2)$ are out of the plane defined by atoms O1-C9 by 2.5 
and $3.4^{\circ}$, respectively. The above mentioned hydroxyl deviations from planarity seem to attribute to $\mathrm{sp}^{3}$ hybridization of $\mathrm{C} 1$. It is interesting to note that the replacement of $\mathrm{H}$ by $\mathrm{Br}$ does not alter the space group. In the crystal structures of chromenes $\mathbf{3 a}$ and $\mathbf{3 c}$, no intermolecular hydrogen-bonds are formed because compounds 3a and 3c present an anti conformation between the ethoxy (O4) and the hydroxy (O2). Thereby, the carboxylate carbonyl $\mathrm{O}$ atom (O3) acts as a hydrogen-bond acceptor allowing the formation of intramolecular hydrogen-bond, and the detailed data for intromolecular hydrogen bond are shown in Table 4. Molecules of $\mathbf{3 a}$ and $\mathbf{3 c}$ are packed in an offset face-to-face arrangement and form a layered stack.

Figure 1. The molecular structures of $\mathbf{3 a}$ and $\mathbf{3 c}$, showing the atomic numbering scheme and displacement ellipsoids draw at the $30 \%$ probability level.

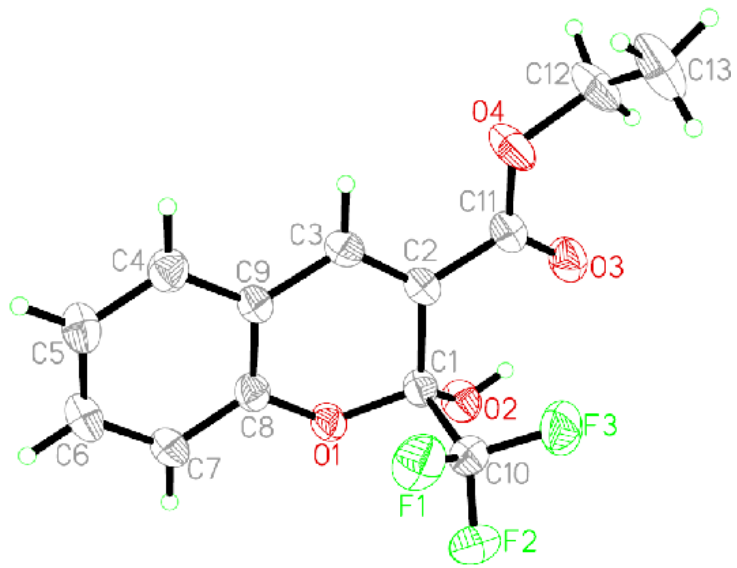

3a

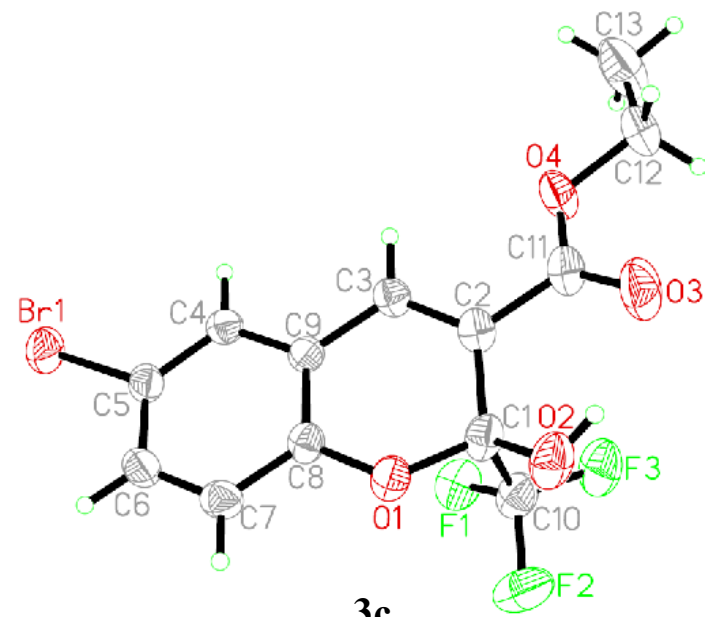

$3 c$

Figure 2. View of the molecular packing in 3a and 3c.
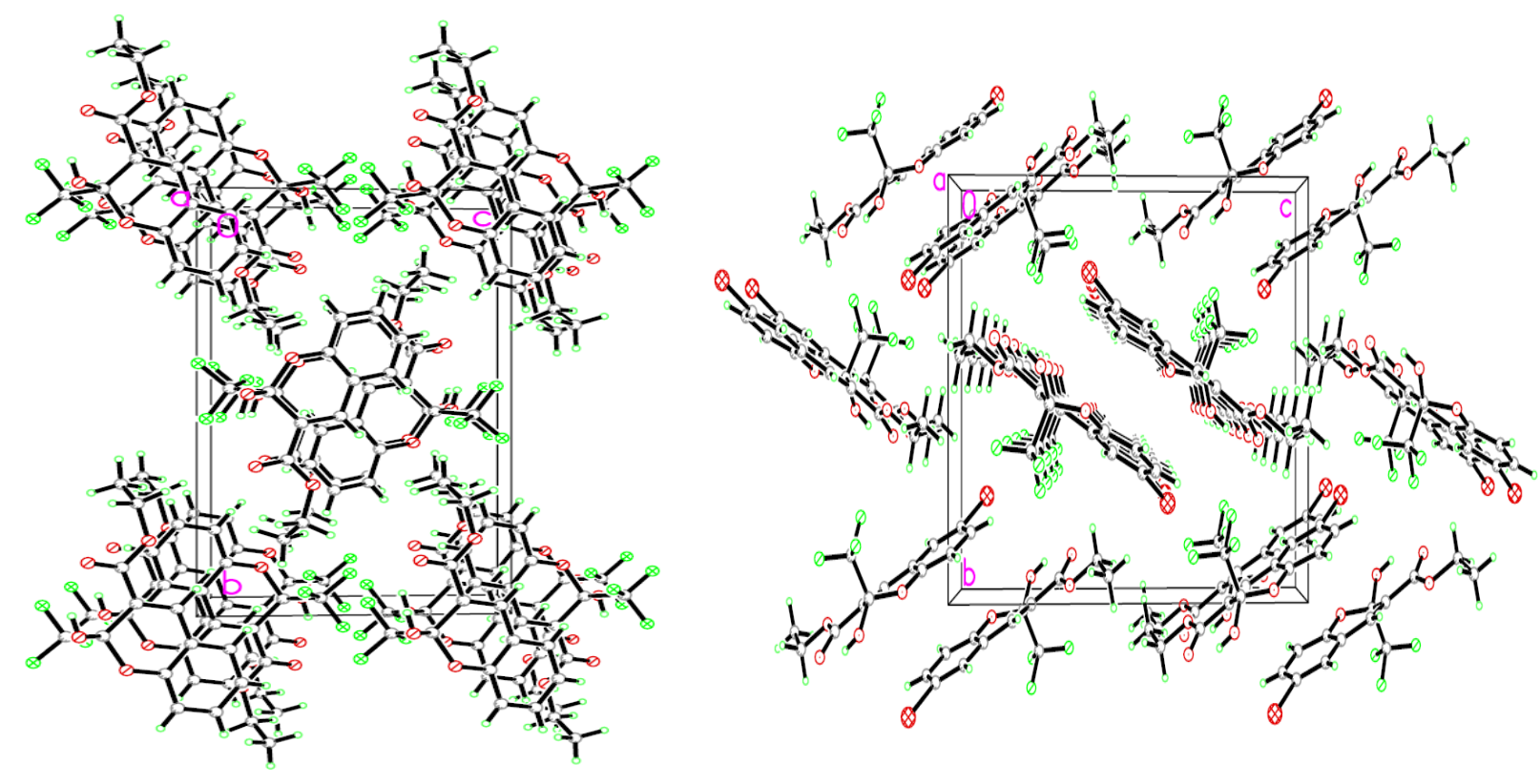
Table 3. Crystal data and structure refinement for 3a and $\mathbf{3 c}$.

\begin{tabular}{ccc}
\hline & 3a & 3c \\
\hline formula & $\mathrm{C}_{13} \mathrm{H}_{11} \mathrm{~F}_{3} \mathrm{O}_{4}$ & $\mathrm{C}_{13} \mathrm{H}_{10} \mathrm{BrF}_{3} \mathrm{O}_{4}$ \\
$F w$ & 288.22 & 367.12 \\
crystal system & monoclinic & monoclinic \\
space group & $P 2(1) / c$ & $P 2(1) / c$ \\
$a(\AA)$ & $8.415(1)$ & $7.085(2)$ \\
$b(\AA)$ & $16.604(3)$ & $12.831(3)$ \\
$c(\AA)$ & $9.443(9)$ & $15.526(3)$ \\
$\beta(\mathrm{deg})$ & $97.51(3)$ & $93.52(3)$ \\
$V\left(\AA^{3}\right)$ & $1308.2(5)$ & $1408.9(5)$ \\
$Z$ & 4 & 4 \\
$T(\mathrm{~K})$ & $293(2)$ & $293(2)$ \\
$D_{\text {calc }}\left(\mathrm{Mg} \mathrm{m}^{-3}\right)$ & 1.463 & 1.731 \\
$\left.\mu(\mathrm{mm})^{-1}\right)$ & 0.135 & 2.964 \\
$R_{I}(I>2 \sigma(I))$ & 0.0792 & 0.0492 \\
$R_{I}($ all data $)$ & 0.0829 & 0.0651 \\
$w R_{2}(I>2 \sigma(I))$ & 0.2261 & 0.1433 \\
$w R_{2}($ all data $)$ & 0.2310 & 0.1553 \\
$G O O F$ & 1.052 & 1.074 \\
\hline
\end{tabular}

Table 4. Hydrogen bonding distances $[\AA]$ and angles $\left[{ }^{\circ}\right]$ for $\mathbf{3 a}$ and $\mathbf{3 c}$.

\begin{tabular}{ccccc}
\hline Crystal & D-H· $\mathbf{A}$ & $\mathbf{d}(\mathbf{D}-\mathbf{H})$ & $\mathbf{d}(\mathbf{D} \cdot \mathbf{A})$ & $\mathbf{D}-\mathbf{H} \cdot \mathbf{A}$ \\
\hline 3a & $\mathrm{O} 2-\mathrm{H} 2 \cdot \mathrm{O} 3$ & 0.82 & $2.71(1)$ & 143 \\
$\mathbf{3 c}$ & $\mathrm{O} 2-\mathrm{H} 2 \cdot \mathrm{O} 3$ & 0.82 & $2.64(1)$ & 147 \\
\hline
\end{tabular}

\section{Experimental}

\subsection{Gereral}

Infrared spectra were recorded with a Nicolet IS10 Fourier Transform Infrared Spectrophotometer (4,000-400 $\mathrm{cm}^{-1}$ ) (KBr pellets). ${ }^{1} \mathrm{H}$ and ${ }^{13} \mathrm{C}$-NMR spectra of $\mathrm{CDCl}_{3}$ solutions were obtained on a Bruker DPX-400 or Advance 300 Spectrometer, respectively. ${ }^{19}$ F-NMR spectra were recorded in $\mathrm{CDCl}_{3}$ without an internal standard. HPLC analyses for the qualitative and quantitative analysis of the products were carried out using an Agilent 1200 pump equipped with an Agilent 1200 detector. High resolution mass spectrometry data were measured on a Waters Q-Tof micro ${ }^{\mathrm{TM}}$ instructment with an electrospray ionization source (ESIMS). X-ray diffraction data were collected on a Rigaku RAXIAS-IV type diffractometer. Melting points were determined on a X-5 digital microscopic melting-point apparatus (Beijing Tech Instruments Co., Beijing, China) and are uncorrected. A household microwave oven (Haier MM-2270MG, Qingdao, China) and electrothermal drying oven (Qin Stewart 101-2AB, Tianjin, China) were used for heating the reaction mixtures.

X-ray Crystallography parameters for data collection and refinement of the compounds are summarized in Table 1. Intensities were collected on a Rigaku Saturn 724 CCD diffractometer (Mo-K $\alpha, \lambda=0.71073 \AA$ ) at a temperature of $293 \mathrm{~K}$ using the SMART and SAINT programs [39]. The 
structures were solved by direct method and refined on F2 by full-matrix least-squares methods with SHELXTL-97 crystallographic software package [40]. All the non-hydrogen atoms were refined with anisotropic thermal displacement coefficients. The hydrogen atoms were assigned with common isotropic displacement factors and included in the final refinement by using geometrical restrains.

All solvents and reagents were used without futher purification.

\subsection{Preparation of Catalyst L-Proline/SiO $\mathrm{S}_{2}$}

Silica (45 g, $200 \mathrm{mesh}$ ) was added to a solution of L-proline (22 mmol) in deionized water (50 $\mathrm{mL})$. After being stirred at room temperature for $30 \mathrm{~min}$, the mixture was first dried at room temperature overnight, and then heated in an oven for $6 \mathrm{~h}$ at $50{ }^{\circ} \mathrm{C}$. The resulting immobilized catalyst was kept in a desiccator for use.

\subsection{General Synthetic Procedures for Compounds 3a-31}

\subsubsection{Oven Heating Procedure}

In a typical experiment of Knoevenagel condensation reaction catalyzed by immobillized L-proline, aldehyde $(7 \mathrm{mmol})$, ethyl trifluoroacetoacetate $(14 \mathrm{mmol})$ and $4.5 \mathrm{~g}$ of L-proline $/ \mathrm{SiO}_{2}$ were thoroughly ground in a mortar. The mixture was charged in a microwave tube (capacity $10 \mathrm{~mL}$ ), then sealed with polytetrafluoroethylene film and heated in an oven at $80{ }^{\circ} \mathrm{C}$ for $6-8 \mathrm{~h}$ (monitored by HPLC). The mixture was allowed to cool to room temperature. Ethyl acetate was added and the resulting mixture was filtered, and the residue was sequentially washed with ethyl acetate or dichloromethane for at least three times. The combined solution was evaporated under reduced pressure, and the crude product was recrystallized from ethanol or ethyl acetate.

\subsubsection{Microwave Irradiation Procedure}

The same procedure and dosage was applied as above. After being mixed fully, the mixture was put into a microwave tube, sealed, irradiated in the microwave oven under $126 \mathrm{~W}$ power. The reaction was monitored by HPLC. After the aldehyde had consumed, the irradiation was terminated and the mixture was allowed to cool to room temperature. The same work-up was as above.

Ethyl 2-hydroxy-2-(trifluoromethyl)-2H-chromene-3-carboxylate (3a) [24]. White solid, yield 76\%, m.p. $103.4-104.2{ }^{\circ} \mathrm{C}$ (Lit. $102.0-103.0{ }^{\circ} \mathrm{C}$ ). IR cm ${ }^{-1}$ : 3,300, 1,695, 1,636, 1,608, 1,575, 1,489; ${ }^{1} \mathrm{H}-\mathrm{NMR}\left(\mathrm{CDCl}_{3}, 300 \mathrm{MHz}\right) \delta: 1.39\left(\mathrm{t}, J=7.2 \mathrm{~Hz}, 3 \mathrm{H}, \mathrm{CH}_{3}\right), 4.36\left(\mathrm{q}, J=7.2 \mathrm{~Hz}, 2 \mathrm{H}, \mathrm{CH}_{2}\right)$, 6.99-7.03 (m, 2H, H-6, H-8), 7.25 (dd, $J=7.9,1.7 \mathrm{~Hz}, 1 \mathrm{H}, \mathrm{H}-5), 7.36$ (m, 1H, H-7), 7.54 (s, 1H, OH), $7.78(\mathrm{~s}, 1 \mathrm{H}, \mathrm{H}-4) ;{ }^{13} \mathrm{C}-\mathrm{NMR}\left(\mathrm{CDCl}_{3}, 75 \mathrm{MHz}\right) \delta: 13.9\left(\mathrm{CH}_{3}\right), 62.6\left(\mathrm{CH}_{2}\right), 95.2\left(\mathrm{q},{ }^{2} J_{\mathrm{C}, \mathrm{F}}=34.8 \mathrm{~Hz}, \mathrm{CCF}_{3}\right)$, 114.6, 115.8, 117.5, 122.6 (q, $\left.{ }^{1} J_{\mathrm{C}, \mathrm{F}}=290 \mathrm{~Hz}, \mathrm{CF}_{3}\right), 122.6,129.5,133.9,139.3,152.5,166.7(\mathrm{C}=\mathrm{O})$; HRMS: calcd for $m / z\left(\mathrm{C}_{13} \mathrm{H}_{11} \mathrm{~F}_{3} \mathrm{O}_{4}+\mathrm{Na}\right)^{+}: 311.0507$; found: 311.0536 .

Ethyl 6-chloro-2-hydroxy-2-(trifluoromethyl)-2H-chromene-3-carboxylate (3b). White solid, m.p. 115.5-116.9 ${ }^{\circ} \mathrm{C}$. IR cm ${ }^{-1}$ : 3,314, 1,700, 1,636, 1,565, 1,460; ${ }^{1} \mathrm{H}-\mathrm{NMR}\left(\mathrm{CDCl}_{3}, 300 \mathrm{MHz}\right)$ $\delta: 1.40\left(\mathrm{t}, J=7.2 \mathrm{~Hz}, 3 \mathrm{H}, \mathrm{CH}_{3}\right), 4.37\left(\mathrm{q}, J=7.2 \mathrm{~Hz}, 2 \mathrm{H}, \mathrm{CH}_{2}\right), 6.98(\mathrm{~d}, J=8.7 \mathrm{~Hz}, 1 \mathrm{H}, \mathrm{H}-8)$, 
$7.24(\mathrm{~d}, J=2.5 \mathrm{~Hz}, \mathrm{H}-5), 7.31$ (dd, $J=8.7,2.5 \mathrm{~Hz}, \mathrm{H}-7), 7.50(\mathrm{~s}, 1 \mathrm{H}, \mathrm{OH}), 7.70$ (s, 1H, H-4); ${ }^{13} \mathrm{C} \mathrm{NMR}\left(\mathrm{CDCl}_{3}, 75 \mathrm{MHz}\right) \delta: 13.9\left(\mathrm{CH}_{3}\right), 62.7\left(\mathrm{OCH}_{2}\right), 95.4\left(\mathrm{q},{ }^{2} J_{\mathrm{C}, \mathrm{F}}=35.1 \mathrm{~Hz}, C_{C F}\right), 116.0,117.4$, 118.7, $122.2\left(\mathrm{q},{ }^{1} J_{\mathrm{C}, \mathrm{F}}=291 \mathrm{~Hz}, \mathrm{CF}_{3}\right), 127.6,128.6,133.4,137.9,151.0,166.4(\mathrm{C}=\mathrm{O})$; HRMS: calcd for $m / z\left(\mathrm{C}_{13} \mathrm{H}_{10} \mathrm{ClF}_{3} \mathrm{O}_{4}+\mathrm{Na}\right)^{+}: 345.0118$; found: 345.0135 .

Ethyl 6-bromo-2-hydroxy-2-(trifluoromethyl)-2H-chromene-3-carboxylate (3c) [24]. Light yellow solid, m.p. $107.0-108.4{ }^{\circ} \mathrm{C}$. IR cm ${ }^{-1}: 3,248,1,684,1,629,1,600,1,564,1,478 ;{ }^{1} \mathrm{H}-\mathrm{NMR}\left(\mathrm{CDCl}_{3}, 300\right.$ MHz) $\delta: 1.39\left(\mathrm{t}, J=7.2 \mathrm{~Hz}, 3 \mathrm{H}, \mathrm{CH}_{3}\right), 4.40\left(\mathrm{q}, J=7.2 \mathrm{~Hz}, 2 \mathrm{H}, \mathrm{CH}_{2}\right), 6.90(\mathrm{~d}, J=8.7 \mathrm{~Hz}, 1 \mathrm{H}, \mathrm{H}-8)$, 7.38 (d, $J=2.4 \mathrm{~Hz}, \mathrm{H}-5), 7.43$ (dd, $J=8.7,2.4 \mathrm{~Hz}, \mathrm{H}-7), 7.47$ (s, 1H, OH), 7.70 (s, 1H, H-4); ${ }^{13} \mathrm{C}-\mathrm{NMR}\left(\mathrm{CDCl}_{3}, 75 \mathrm{MHz}\right) \delta: 13.9\left(\mathrm{CH}_{3}\right), 62.7\left(\mathrm{OCH}_{2}\right), 95.3\left(\mathrm{q},{ }^{2} J_{\mathrm{C}, \mathrm{F}}=35.0 \mathrm{~Hz}, \mathrm{CCF}_{3}\right), 114.6,115.9$, 117.7, 119.1, 122.4 (q, $\left.{ }^{1} J_{\mathrm{C}, \mathrm{F}}=290 \mathrm{~Hz}, \mathrm{CF}_{3}\right), 131.6,136.3,137.8,151.4,166.3(\mathrm{C}=\mathrm{O})$; HRMS: calcd for $m / z\left(\mathrm{C}_{13} \mathrm{H}_{10} \mathrm{BrF}_{3} \mathrm{O}_{4}+\mathrm{Na}\right)^{+}: 388.9613$; found: 388.9634 .

Ethyl 6,8-dichloro-2-hydroxy-2-(trifluoromethyl)-2H-chromene-3-carboxylate (3d). White solid, m.p. 129.6-131.3 ${ }^{\circ} \mathrm{C}$. IR cm ${ }^{-1}: 3,443,1,709,1,631,1,564,1,457 ;{ }^{1} \mathrm{H}-\mathrm{NMR}\left(\mathrm{CDCl}_{3}, 300 \mathrm{MHz}\right) \delta: 1.41$ $\left(\mathrm{t}, J=7.2 \mathrm{~Hz}, 3 \mathrm{H}, \mathrm{CH}_{3}\right), 4.41\left(\mathrm{q}, J=7.2 \mathrm{~Hz}, 2 \mathrm{H}, \mathrm{CH}_{2}\right), 7.17(\mathrm{~d}, J=2.4 \mathrm{~Hz}, 1 \mathrm{H}, \mathrm{H}-7), 7.41$ $(\mathrm{d}, J=2.4 \mathrm{~Hz}, 1 \mathrm{H}, \mathrm{H}-5), 7.56$ (broad, $1 \mathrm{H}, \mathrm{OH}), 7.69(\mathrm{~s}, 1 \mathrm{H}, \mathrm{H}-4) ;{ }^{19} \mathrm{~F}-\mathrm{NMR}\left(\mathrm{CDCl}_{3}, 376.5 \mathrm{MHz}\right) \delta$ : $-87.15(\mathrm{~s}, 3 \mathrm{~F}) ;{ }^{13} \mathrm{C}-\mathrm{NMR}\left(\mathrm{CDCl}_{3}, 75 \mathrm{MHz}\right) \delta$ : $13.9\left(\mathrm{CH}_{3}\right), 62.9\left(\mathrm{OCH}_{2}\right), 96.0\left(\mathrm{q},{ }^{2} J_{\mathrm{C}, \mathrm{F}}=35.3 \mathrm{~Hz}, \mathrm{CCF}_{3}\right)$, 117.0, 119.7, 122.1, 122.2 (q, $\left.{ }^{1} J_{\mathrm{C}, \mathrm{F}}=290 \mathrm{~Hz}, \mathrm{CF}_{3}\right), 127.1,127.5,133.3,137.3,147.0,166.0(\mathrm{C}=\mathrm{O})$; HRMS: calcd for $m / z\left(\mathrm{C}_{13} \mathrm{H}_{9} \mathrm{Cl}_{2} \mathrm{~F}_{3} \mathrm{O}_{4}+\mathrm{Na}\right)^{+}: 378.9728$; found: 378.9755 .

Ethyl 6,8-dibromo-2-hydroxy-2-(trifluoromethyl)-2H-chromene-3-carboxylate (3e). White solid, m.p. 114.0-115.1 ${ }^{\circ} \mathrm{C} . \mathrm{IR} \mathrm{cm}{ }^{-1}: 3,251,1,678,1,624,1,554,1,470 ;{ }^{1} \mathrm{H}-\mathrm{NMR}\left(\mathrm{CDCl}_{3}, 300 \mathrm{MHz}\right) \delta: 1.39$ (t, $\left.J=5.4 \mathrm{~Hz}, 3 \mathrm{H}, \mathrm{CH}_{3}\right), 4.38$ (q, $\left.J=5.4 \mathrm{~Hz}, 2 \mathrm{H}, \mathrm{CH}_{2}\right), 7.33$ (d, $\left.J=2.4 \mathrm{~Hz}, 1 \mathrm{H}, \mathrm{H}-7\right), 7.47$ (s, 1H, OH), 7.64 (s, 1H, H-4), $7.70(\mathrm{~d}, J=2.4 \mathrm{~Hz}, 1 \mathrm{H}, \mathrm{H}-5) ;{ }^{13} \mathrm{C}-\mathrm{NMR}\left(\mathrm{CDCl}_{3}, 100 \mathrm{MHz}\right) \delta: 14.0\left(\mathrm{CH}_{3}\right), 62.9\left(\mathrm{CH}_{2}\right), 95.6$ $\left(\mathrm{q},{ }^{2} J_{\mathrm{C}, \mathrm{F}}=36.4 \mathrm{~Hz}, \mathrm{CCF}_{3}\right), 110.9,114.7,116.9,120.1,122.2\left(\mathrm{q},{ }^{1} J_{\mathrm{C}, \mathrm{F}}=290 \mathrm{~Hz}, \mathrm{CF}_{3}\right), 130.7$, 137.3, 138.8, 148.6, $166.0(\mathrm{C}=\mathrm{O})$; HRMS: calcd for $m / z\left(\mathrm{C}_{13} \mathrm{H}_{9} \mathrm{Br}_{2} \mathrm{~F}_{3} \mathrm{O}_{4}+\mathrm{Na}\right)^{+}:$466.8700; found: 466.8764 .

Ethyl 2-hydroxy-8-methoxy-2-(trifluoromethyl)-2H-chromene-3-carboxylate (3f). Light yellow solid, m.p. 99.4-99.9 ${ }^{\circ} \mathrm{C}$. IR cm ${ }^{-1}: 3,328,1,699,1,637,1,610,1,581,1,483 ;{ }^{1} \mathrm{H}-\mathrm{NMR}\left(\mathrm{CDCl}_{3}, 300 \mathrm{MHz}\right)$ $\delta: 1.40\left(\mathrm{t}, J=7.2 \mathrm{~Hz}, 3 \mathrm{H}, \mathrm{CH}_{3}\right), 3.89\left(\mathrm{~s}, 3 \mathrm{H}, \mathrm{CH}_{3} \mathrm{O}\right), 4.37\left(\mathrm{q}, J=7.2 \mathrm{~Hz}, 2 \mathrm{H}, \mathrm{CH}_{2}\right), 6.86(\mathrm{dd}, J=7.2$, $1.9 \mathrm{~Hz}, 1 \mathrm{H}, \mathrm{H}-7), 6.96-7.02$ (m, 2H, H-5, H-6), 7.50 (s, 1H, OH), 7.76 (s, 1H, H-4); ${ }^{13} \mathrm{C}-\mathrm{NMR}\left(\mathrm{CDCl}_{3}\right.$, $75 \mathrm{MHz}) \delta$ : $14.0\left(\mathrm{CH}_{3}\right), 56.4\left(\mathrm{OCH}_{3}\right), 62.4\left(\mathrm{CH}_{2}\right), 95.4\left(\mathrm{q},{ }^{2} J_{\mathrm{C}, \mathrm{F}}=34.8 \mathrm{~Hz}, C \mathrm{CF}_{3}\right), 114.8,117.0,118.2$, 121.2, 122.4, $122.6\left(\mathrm{q},{ }^{1} J_{\mathrm{C}, \mathrm{F}}=290 \mathrm{~Hz}, \mathrm{CF}_{3}\right), 139.4,142.0,147.5,166.7(\mathrm{C}=\mathrm{O})$; HRMS: calcd for $\mathrm{m} / \mathrm{z}$ $\left(\mathrm{C}_{14} \mathrm{H}_{13} \mathrm{~F}_{3} \mathrm{O}_{5}+\mathrm{Na}\right)^{+}:$341.0623; found: 341.0692 .

Ethyl 2-hydroxy-7-methoxy-2-(trifluoromethyl)-2H-chromene-3-carboxylate (3g). White solid, m.p. 76.0-76.5 ${ }^{\circ} \mathrm{C}$. IR cm ${ }^{-1}: 3,326,1,684,1,629,1,569,1,512,1,469 ;{ }^{1} \mathrm{H}-\mathrm{NMR}\left(\mathrm{CDCl}_{3}, 400 \mathrm{MHz}\right)$ $\delta: 1.38\left(\mathrm{t}, J=7.2 \mathrm{~Hz}, 3 \mathrm{H}, \mathrm{CH}_{3}\right), 3.82\left(\mathrm{~s}, 3 \mathrm{H}, \mathrm{CH}_{3} \mathrm{O}\right), 4.34\left(\mathrm{q}, J=7.2 \mathrm{~Hz}, 2 \mathrm{H}, \mathrm{CH}_{2}\right), 6.56-6.58(\mathrm{~m}, 2 \mathrm{H}$, H-5, H-8), 7.16 (dd, J=7.2, $2.0 \mathrm{~Hz}, 1 \mathrm{H}, \mathrm{H}-6), 7.60$ (s, $1 \mathrm{H}, \mathrm{OH}), 7.74$ (s, 1H, H-4); ${ }^{13} \mathrm{C}-\mathrm{NMR}\left(\mathrm{CDCl}_{3}\right.$, $100 \mathrm{MHz}) \delta$ : $14.0\left(\mathrm{CH}_{3}\right), 55.6\left(\mathrm{CH}_{3} \mathrm{O}\right), 62.1\left(\mathrm{CH}_{2}\right), 95.6\left(\mathrm{q},{ }^{2} J_{\mathrm{C}, \mathrm{F}}=34.8 \mathrm{~Hz}, C \mathrm{CF}_{3}\right), 101.0,109.7$, 
110.9, 111.2, $122.8\left(\mathrm{q},{ }^{1} J_{\mathrm{C}, \mathrm{F}}=291 \mathrm{~Hz}, \mathrm{CF}_{3}\right), 130.7,139.4,154.5,164.6,167.1(\mathrm{C}=\mathrm{O})$; HRMS: calcd for $m / z\left(\mathrm{C}_{14} \mathrm{H}_{13} \mathrm{~F}_{3} \mathrm{O}_{5}+\mathrm{Na}\right)^{+}: 341.0623$; found: 341.0664 .

Ethyl 8-ethoxy-2-hydroxy-2-(trifluoromethyl)-2H-chromene-3-carboxylate (3h). White solid, m.p. $112.5-113.9{ }^{\circ} \mathrm{C}$. IR cm ${ }^{-1}: 3,301,1,681,1,632,1,610,1577,1,486 ;{ }^{1} \mathrm{H}-\mathrm{NMR}\left(\mathrm{CDCl}_{3}, 300 \mathrm{MHz}\right)$ $\delta: 1.37-1.44\left(\mathrm{~m}, 6 \mathrm{H}, 2 \mathrm{CH}_{3}\right), 4.07-4.17\left(\mathrm{~m}, 2 \mathrm{H}, \mathrm{CH}_{2}\right), 4.37\left(\mathrm{q}, J=7.2 \mathrm{~Hz}, 2 \mathrm{H}, \mathrm{CH}_{2}\right), 6.85-6.88$ (dd, $J=7.5,1.7 \mathrm{~Hz}, 1 \mathrm{H}, \mathrm{H}-7), 6.91-7.03$ (m, 2H, H-5, H-6), 7.46 (s, 1H, OH), 7.76 (s, 1H, H-4); ${ }^{13} \mathrm{C}-\mathrm{NMR}\left(\mathrm{CDCl}_{3}, 75 \mathrm{MHz}\right)$ \&: $13.9\left(\mathrm{CH}_{3}\right), 14.9\left(\mathrm{CH}_{3}\right), 62.3\left(\mathrm{CH}_{2}\right), 65.4\left(\mathrm{CH}_{2}\right), 95.9\left(\mathrm{q},{ }^{2} J_{\mathrm{C}, \mathrm{F}}=34.8 \mathrm{~Hz}\right.$, $\left.\mathrm{CCF}_{3}\right), 114.7,118.3,119.3,121.4,122.3,122.6\left(\mathrm{q},{ }^{1} J_{\mathrm{C}, \mathrm{F}}=290 \mathrm{~Hz}, \mathrm{CF}_{3}\right), 139.6,142.5,146.7,166.7$ $(\mathrm{C}=\mathrm{O})$; HRMS: calcd for $m / z\left(\mathrm{C}_{15} \mathrm{H}_{15} \mathrm{~F}_{3} \mathrm{O}_{5}+\mathrm{Na}\right)^{+}: 355.0769$; found: 355.0752 .

Ethyl 2-hydroxy-6-methyl-2-(trifluoromethyl)-2H-chromene-3-carboxylate (3i). White solid, m.p. 81.8-82.9 ${ }^{\circ} \mathrm{C}$. IR cm ${ }^{-1}: 3,315,1,682,1,633,1,613,1,582,1,493 ;{ }^{1} \mathrm{H}-\mathrm{NMR}\left(\mathrm{CDCl}_{3}, 400 \mathrm{MHz}\right)$ $\delta: 1.37\left(\mathrm{t}, J=7.2 \mathrm{~Hz}, 3 \mathrm{H}, \mathrm{CH}_{3}\right), 2.28\left(\mathrm{~s}, 3 \mathrm{H}, \mathrm{CH}_{3}\right), 4.36\left(\mathrm{q}, J=7.2 \mathrm{~Hz}, 2 \mathrm{H}, \mathrm{CH}_{2}\right), 6.90(\mathrm{~d}, J=8.4 \mathrm{~Hz}$, 1H, H-8), 7.04 (s, 1H, H-5), 7.11 (dd, $J=8.4,1.6 \mathrm{~Hz}, 1 \mathrm{H}, \mathrm{H}-7), 7.22$ (s, 1H, OH), 7.73 (s, 1H, H-4); ${ }^{13} \mathrm{C}-\mathrm{NMR}\left(\mathrm{CDCl}_{3}, 100 \mathrm{MHz}\right) \delta: 13.9\left(\mathrm{CH}_{3}\right), 20.2\left(\mathrm{CH}_{3}\right), 62.3\left(\mathrm{CH}_{2}\right), 95.3\left(\mathrm{q},{ }^{2} J_{\mathrm{C}, \mathrm{F}}=34.7 \mathrm{~Hz}, \mathrm{CCF}_{3}\right)$, 114.6, 115.6, 117.3, 122.7 (q, $\left.{ }^{1} J_{\mathrm{C}, \mathrm{F}}=291 \mathrm{~Hz}, \mathrm{CF}_{3}\right), 129.6,132.1,134.6,139.5,150.5,166.8(\mathrm{C}=\mathrm{O})$; HRMS: calcd for $m / z\left(\mathrm{C}_{14} \mathrm{H}_{13} \mathrm{~F}_{3} \mathrm{O}_{4}+\mathrm{Na}\right)^{+}$: 325.0664; found: 325.0666 .

Ethyl 2,7-dihydroxy-2-(trifluoromethyl)-2H-chromene-3-carboxylate (3j). White solid, m.p. 152.0-153.2 ${ }^{\circ} \mathrm{C}$. IR cm ${ }^{-1}: 3,110,1,696,1,608,1,510,1,460 ;{ }^{1} \mathrm{H}-\mathrm{NMR}\left(\mathrm{CDCl}_{3}, 400 \mathrm{MHz}\right) \delta: 1.26(\mathrm{t}, J=7.2 \mathrm{~Hz}, 3 \mathrm{H}$, $\left.\mathrm{CH}_{3}\right), 4.14-4.25\left(\mathrm{~m}, 2 \mathrm{H}, \mathrm{CH}_{2}\right), 6.38$ (s, 1H, H-8), 6.49 (dd, J=8.4, $\left.1.6 \mathrm{~Hz}, 1 \mathrm{H}, \mathrm{H}-6\right), 7.34$ (d, J=8.4 $\mathrm{Hz}, 1 \mathrm{H}, \mathrm{H}-5), 7.87$ (s, 1H, H-4), 8.83 (broad, $1 \mathrm{H}, \mathrm{OH}), 10.37$ (broad, $1 \mathrm{H}, \mathrm{OH}) ;{ }^{13} \mathrm{C}-\mathrm{NMR}\left(\mathrm{CDCl}_{3}\right.$, $100 \mathrm{MHz}) \delta: 14.3\left(\mathrm{CH}_{3}\right), 60.5\left(\mathrm{CH}_{2}\right), 96.3\left(\mathrm{q},{ }^{2} J_{\mathrm{C}, \mathrm{F}}=40.0 \mathrm{~Hz}, C_{C F}\right), 102.1,109.6,110.5,114.8,122.6$ $\left(\mathrm{q},{ }^{1} J_{\mathrm{C}, \mathrm{F}}=288 \mathrm{~Hz}, \mathrm{CF}_{3}\right), 131.3,139.4,154.0,162.7,163.4(\mathrm{C}=\mathrm{O})$; HRMS: calcd for $\mathrm{m} / \mathrm{z}$ $\left(\mathrm{C}_{14} \mathrm{H}_{11} \mathrm{~F}_{3} \mathrm{O}_{5}+\mathrm{Na}\right)^{+}:$327.0456; found: 327.0455 .

Ethyl 2-hydroxy-6-nitro-2-(trifluoromethyl)-2H-chromene-3-carboxylate (3k) [24]. Light yellow solid, m.p. $120.0-120.7{ }^{\circ} \mathrm{C}$ (Lit. $120-120.5{ }^{\circ} \mathrm{C}$ ). IR cm ${ }^{-1}$ : 3,426, 1,721, 1,619, 1,517, 1,478; ${ }^{1} \mathrm{H}-\mathrm{NMR}$ $\left(\mathrm{CDCl}_{3}, 400 \mathrm{MHz}\right) \delta: 1.32\left(\mathrm{t}, J=7.2 \mathrm{~Hz}, 3 \mathrm{H}, \mathrm{CH}_{3}\right), 4.29$ (q, $\left.J=7.2 \mathrm{~Hz}, 2 \mathrm{H}, \mathrm{CH}_{2}\right), 7.28(\mathrm{~d}, J=9.2 \mathrm{~Hz}$, $1 \mathrm{H}, \mathrm{H}-8), 8.19$ (s, 1H, H-4), 8.29 (dd, $J=9.2,2.4 \mathrm{~Hz}, 1 \mathrm{H}, \mathrm{H}-7), 8.61$ (d, $J=2.4 \mathrm{~Hz}, 1 \mathrm{H}, \mathrm{H}-5)$, 9.60 (broad, $1 \mathrm{H}, \mathrm{OH}) ;{ }^{13} \mathrm{C}-\mathrm{NMR}\left(\mathrm{CDCl}_{3}, 100 \mathrm{MHz}\right) \delta: 14.1\left(\mathrm{CH}_{3}\right), 61.3\left(\mathrm{CH}_{2}\right), 97.1\left(\mathrm{q},{ }^{2} J_{\mathrm{C}, \mathrm{F}}=34.5 \mathrm{~Hz}\right.$, $\left.C_{C F}\right), 116.8,117.7,121.5,122.1\left(\mathrm{q},{ }^{1} J_{\mathrm{C}, \mathrm{F}}=288 \mathrm{~Hz}, \mathrm{CF}_{3}\right), 125.6,128.5,137.0,142.4,156.5,162.6$ $(\mathrm{C}=\mathrm{O})$. HRMS: calcd for $m / z\left(\mathrm{C}_{13} \mathrm{H}_{10} \mathrm{~F}_{3} \mathrm{O}_{6}+\mathrm{Na}\right)^{+}$: 356.0358; found: 356.0360 .

Ethyl 2-hydroxy-2-(trifluoromethyl)-2H-benzo[h]chromene-3-carboxylate (31). Yellow solid, m.p. 123.9.0-124.8 ${ }^{\circ} \mathrm{C}$. IR cm ${ }^{-1}: 3,224,1,671,1,614,1,592,1,570,1,519,1,465 ;{ }^{1} \mathrm{H}-\mathrm{NMR}\left(\mathrm{CDCl}_{3}\right.$, $400 \mathrm{MHz}) \delta: 1.48\left(\mathrm{t}, J=7.2 \mathrm{~Hz}, 3 \mathrm{H}, \mathrm{CH}_{3}\right), 4.46\left(\mathrm{q}, J=7.2 \mathrm{~Hz}, 2 \mathrm{H}, \mathrm{CH}_{2}\right), 7.24(\mathrm{~m}, 1 \mathrm{H}, \mathrm{ArH})$, $7.48(\mathrm{~m}, 1 \mathrm{H}, \mathrm{ArH}), 7.62(\mathrm{~m}, 1 \mathrm{H}, \mathrm{ArH}), 7.80-7.82(\mathrm{~m}, 2 \mathrm{H}, \operatorname{ArH}, \mathrm{OH}), 7.89(\mathrm{~m}, 1 \mathrm{H}, \operatorname{ArH})$, $8.06(\mathrm{~m}, 1 \mathrm{H}, \mathrm{ArH}), 8.47(\mathrm{~d}, J=3.6 \mathrm{~Hz}, 1 \mathrm{H}, \mathrm{ArH}) ;{ }^{13} \mathrm{C}-\mathrm{NMR}\left(\mathrm{CDCl}_{3}, 100 \mathrm{MHz}\right) \delta: 14.1\left(\mathrm{CH}_{3}\right)$, $62.5\left(\mathrm{CH}_{2}\right), 95.6\left(\mathrm{q},{ }^{2} J_{\mathrm{C}, \mathrm{F}}=35.0 \mathrm{~Hz}, \mathrm{CCF}_{3}\right), 110.6,112.3,116.6,120.8,122.7\left(\mathrm{q},{ }^{1} J_{\mathrm{C}, \mathrm{F}}=291 \mathrm{~Hz}, \mathrm{CF}_{3}\right)$, $125.0,128.3,128.9,129.5,130.1,134.9,135.1,152.2,167.0(\mathrm{C}=\mathrm{O})$. HRMS: calcd for $\mathrm{m} / \mathrm{z}$ $\left(\mathrm{C}_{17} \mathrm{H}_{13} \mathrm{~F}_{3} \mathrm{O}_{4}+\mathrm{Na}\right)^{+}: 361.0664$; found: 361.0663 . 


\section{Conclusion}

In summary, silica-immobilized L-proline has been employed as an efficient catalyst for the solvent-free preparation of 2-hydroxy-2-(trifluoromethyl)-2H-chromene-3-carboxylates. The reaction proceeded via a tandem condensation-cyclization process and gave the title products in good yields. This environmentally friendly synthetic method possesses such advantages as operational simplicity, environmentally friendliness, good catalytic performance, reusability, and reduction of time when combined with MW irradiation.

\section{Supplementary Materials}

Supplementary materials can be accessed at: http://www.mdpi.com/1420-3049/18/10/11964/s1.

\section{Acknowledgments}

We are grateful for the financial support for this work from the Key Science and Technique Foundation of Henan Province (112101110200).

\section{Conflicts of Interest}

The authors declare no conflict of interest

\section{References}

1. Curini, M.; Cravotto, G.; Epifano, F.; Giannone, G. Chemistry and biological activity of natural and synthetic prenyloxycoumarins. Curr. Med. Chem. 2006, 13, 199-222.

2. Monga, P.K.; Sharma, D.; Dubey, A. Comparative Study of Microwave and Conventional Synthesis and Pharmacological activity of Coumarins: A Review. J. Chem. Pharm. Res. 2012, 4, $822-850$.

3. Schweizer, E.E.; Meeder-Nycz, D. Chromenes, Chromanes, Chromones, Ellis, G.P., Ed.; Wiley-Interscience: New York, NY, USA, 1977.

4. Bedoya, L.M.; Beltrán, M.; Sancho, R.; Olmedo, D.A.; Sánchez-Palomino, S.; del Olmo, E.; López-Pérez, J.L.; Muñoz, E.; San Feliciano, A.; Alcamí, J. 4-Phenylcoumarins as HIV transcription inhibitors. Bioorg. Med. Chem. Lett. 2005, 21, 4447-4450.

5. Yu, D.; Suzuki, M.; Xie, L.; Morris-Natschke, S.L.; Lee, K.H. Recent progress in the development of coumarin derivatives as potent anti-HIV agents. Med. Res. Rev. 2003, 23, 322-345.

6. Xiao, G.Q.; Liang, B.X.; Chen, S.H.; Ou, T.M.; Bu, X.Z.; Yan, M. 3-Nitro-2H-chromenes as a new class of inhibitors against thioredoxin reductase and proliferation of cancer cells. Arch. Pharm. Chem. Life Sci. 2012, 345, 767-770.

7. Thomas, N.; Zachariah, S.M. Pharmacological activities of chromene derivatives: An overview. Asian J. Pharm. Clin. Res. 2011, 6, 11-15. 
8. Abdel-Wahab, A.H.F.; Mohamed, H.M.; El-Agrody, A.M.; El-Nassag, M.A.; Bedair, A.H. Synthesis and reactions of some new benzylphthalazin-1-ylaminophenols, $2 H$-chromene and $5 H$-chromeno[2,3-d]pyrimidine derivatives with promising antimicrobial activities. Lett. Org. Chem. 2012, 9, 360-367.

9. Kidwai, M.; Saxena, S.; Khan, M.K.; Thukral, S.S. Aqua mediated synthesis of substituted 2-amino-4H-chromenes and in vitro study as antibacterial agents. Bioorg. Med. Chem. Lett. 2005, 15, 4295-4298.

10. Lago, J.H.; Ramos, C.S.; Casanova, D.C.; Morandim, A.A.; Bergamo, D.C.; Cavalheiro, A.J.; Bolzani, V.S.; Furlan, M.; Guimarães, E.F.; Young, M.C.; et al. Benzoic acid derivatives from Piper species and their fungitoxic activity against Cladosporium cladosporioides and C. sphaerospermum. J. Nat. Prod. 2004, 67, 1783-1788.

11. Mukai, K.; Okabe, K.; Hosose, H. Synthesis and stopped-flow investigation of antioxidant activity of tocopherols. Finding of new tocopherol derivatives having the highest antioxidant activity among phenolic antioxidants. J. Org. Chem. 1989, 54, 557-560.

12. Bernard, C.B.; Krishanmurty, H.G.; Chauret, D.; Durst, T.; Philogène, B.J.R.; Sánchez-Vindas, P.; Hasbun, C.; Poveda, L.; San Román, L.; Arnason, J.T. Insecticidal defenses of Piperaceae from the neotropics. J. Chem. Ecol. 1995, 21, 801-814.

13. Evans, J.M.; Fake, C.S.; Hamilton, T.C.; Poyser, R.H.; Watts, E.A. Synthesis and antihypertensive activity of substituted trans-4-amino-3,4-dihydro-2,2-dimethyl-2H-1benzopyran-3-ols. J. Med. Chem. 1983, 26, 1582-1589.

14. Thompson, R.; Doggrell, S.; Hoberg, J.O. Potassium channel activators based on the benzopyran substructure: Synthesis and activity of the C-8 substituent. Bioorgan. Med. Chem. 2003, 11, 1663-1668.

15. O'Hagen, D.; Rzepa, H.S. Some influences of fluorine in bioorganic chemistry. Chem. Commun. 1997, doi:10.1039/A604140J.

16. Ojima, I.; Taguchi, T.; Ojima, I. Fluorine in Medicinal Chemistry and Chemical Biology; Wiley-Blackwell: Chicester, UK, 2009.

17. Uneyama, K. Organofluorine Chemistry; Blackwell Publishing Ltd.: Oxford, UK, 2006.

18. Ojima, I.; McCarthy, J.R.; Welch, J.T. Biomedical Frontiers of Fluorine Chemistry; American Chemical Society: Washington, DC, USA, 1996.

19. Arnone, A.; Bernardi, R.; Blasco, F.; Cardillo, R.; Resnati, G.; Gerus, I.I.; Kukhar, V.P. Trifluoromethyl vs. methyl ability to direct enantioselection in microbial reduction of carbonyl substrates. Tetrahedron 1998, 54, 2809-2818.

20. Kharrat, S.E.; Laurent, P.; Blancou, H. Novel synthesis of 2-(trifluoromethyl)- and 2-(perfluoroalkyl)-2-hydroxy-2H-chromenes and their regiospecific reaction with silyl enol ethers. J. Org. Chem. 2006, 71, 8637-8640.

21. Wang, J.L.; Carter, J.; Kiefer J.R.; Kurumbail, R.G.; Pawlitz, J.L.; Brown, D.; Hartmann, S.J.; Graneto, M.J.; Seibert, K.; John, J.; et al. The novel benzopyran class of selective cyclooxygenase-2 inhibitors. Part I: The first clinical candidate. Bioorg. Med. Chem. Lett. 2010, 20, 7155-7158. 
22. Wang, J.L.; Limburg, D.; Graneto, M.J.; Springer, J.; Hamper, J.R.; Liao, S.; Pawlitz, J.L.; Kurumbail, R.G.; Maziasz, T.; Talley, J.J.; et al. The novel benzopyran class of selective cyclooxygenase-2 inhibitors. Part II: The second clinical candidate having a shorter and favorable human half-life. Bioorg. Med. Chem. Lett. 2010, 20, 7159-7163.

23. Wang, J.L.; Aston, K.; Limburg, D.; Ludwig, C.; Hallinan, A.E.; Koszyk, F.; Hamper, B.; Brown, D.; Graneto, M.; Talley, J.; et al. The novel benzopyran class of selective cyclooxygenase-2 inhibitors. Part III: The three microdose candidates. Bioorg. Med. Chem. Lett. 2010, 20, 7164-7168.

24. Chizhov, D.L.; Sosnovskikh, V.Y.; Pryadeina, M.V.; Burgart, Y.V.; Saloutin, V.I.; Charushin, V.N. The first synthesis of 4-unsubstituted 3-(trifluoroacetyl)coumarins by the Knoevenagel condensation of salicylaldehydes with ethyl trifluoroacetoacetate followed by chromene-coumarin recyclization. Synlett 2008, 2, 281-285.

25. Li, H.Q.; Cai, L.; Li, J.X.; Hu, Y.X.; Zhou, P.P.; Zhang, J.M. Novel coumarin fluorescent dyes: Synthesis, structural characterization and recognition behavior towards $\mathrm{Cu}(\mathrm{II})$ and $\mathrm{Ni}(\mathrm{II})$. Dyes Pigments 2011, 91, 309-316.

26. Wan, P.; Han, J.W.; Zhao, J.W.; Zhu, S.Z. Regioselective carbon-Carbon bond formation in the reaction of 2-hydroxy-2-(trifluoromethyl)- $\mathrm{H}$-chromenes with indoles promoted by Lewis acid. Synthesis 2011, 20, 3364-3370.

27. Li, X.J.; Zhao, J.W.; Wang, Z.W.; Han, J.W.; Zhao, J.; Zhu, S.Z. Reactions of 2-(trifluoromethyl)2-hydroxy-2H-chromenes with thiophenols promoted by Lewis acid. Tetrahedron 2012, 68, 8011-8017.

28. Tanaka, K. Solvent-Free Organic Synthesis; Wiley-VCH: Weinheim, Germany, 2003.

29. Hodnett, B.K.; Kybett, A.P.; Clark, J.H., Smith, K. Supported Reagents and Catalysts in Chemistry; RSC Cambridge: Cambridge, UK, 1998.

30. Wang, L.M.; Sheng, J.; Tian, H.; Han, J.W.; Fan, Z.Y.; Qian, C.T. A convenient synthesis of $\alpha, \alpha^{\prime}$-bis(substituted benzylidene)cycloalkanones catalyzed by $\mathrm{Yb}(\mathrm{OTf})_{3}$ under solvent-free conditions. Synthesis 2004, 18, 3060-3064.

31. Hou, C.; Zhu, H.; Li, Y.J.; Li, Y.F. Immobilized proline and its derivatives employed in the catalysis of asymmetric organic synthesis. Prog. Chem. 2012, 24, 1729-1741.

32. Font, D.; Jimeno, C.; Pericàs, M.A. Polystyrene-supported hydroxyproline: An insoluble, recyclable organocatalyst for the asymmetric aldol reaction in water. Org. Lett. 2006, 8, 4653-4655.

33. Yang, H.L.; Li, S.W.; Wang, X.Y.; Zhang, F.W.; Zhong, X.; Dong, Z.P.; Ma, J.T. Core-shell silica magnetic microspheres supported proline as a recyclable organocatalyst for the asymmetric aldol reaction. J. Mol. Catal. A Chem. 2012, 363-364, 404-410.

34 Li, J.; Yang, G.X.; Qin, Y.Y.; Yang, X.R.; Cui, Y.C. Recyclable Merrifield resin-supported thiourea organocatalysts derived from L-proline for direct asymmetric aldol reaction. Tetrahedron Asymmetry 2011, 22, 613-618.

35. Zhao, Y.B.; Zhang, L.W.; Wu, L.Y.; Zhong, X.; Li, R.; Ma, J.T. Silica-supported pyrrolidine-triazole, an insoluble, recyclable organocatalyst for the enantioselective Michael addition of ketones to nitroalkenes. Tetrahedron Asymmetry 2008, 19, 1352-1355.

36. Yang, G.Y.; Wang, C.X.; Fan, S.F.; Zhao, L.J.; Wang, D.; Xu, C.L. Study on the cyclization methods of 3-[1-(phenylhydrazono)ethyl]-chromen-2-ones. Synth. Commun. 2013, 43, 1263-1269. 
37. Yang, G.Y.; Yang, J.T.; Wang, C.X.; Fan, S.F.; Xie, P.H., Xu, C.L. Microwave-assisted synthesis of 3-methyl-1-phenylchromeno[4,3-c]pyrazol-4(1H)-ones under solvent-free conditions. Heterocycles 2013, 87, 1327-1336.

38. Wen, L.L.; Zhang, H.H.; Lin, H.; Shen, Q.L.; Lu, L. A facile synthetic route to 2-trifluoromethylsubstituted polyfunctionalized chromenes and chromones. J. Fluorine Chem. 2012, 133, 171-177.

39. Smart and Saint. Area Detector Control, Integration Software; Siemens Analytical X-ray Systems, Inc.: Madison, WI, USA, 1996.

40. Sheldrick, G.M. SHELXTL V5.1, Software Reference Manual; Bruker AXS, Inc.: Madison, WI, USA, 1997.

Sample Availability: Samples of the compounds are available from the authors.

(C) 2013 by the authors; licensee MDPI, Basel, Switzerland. This article is an open access article distributed under the terms and conditions of the Creative Commons Attribution license (http://creativecommons.org/licenses/by/3.0/). 